\title{
PENGARUH PEMBELAJARAN JARAK JAUH TERHADAP SEMANGAT BELAJAR MAHASISWI SEMESTER III PROGRAM STUDI PENDIDIKAN AGAMA ISLAM FAKULTAS TARBIYAH INSTITUT ILMU AL-QUR'AN (IIQ) JAKARTA
}

\author{
Nur Kholifah \\ Faza Karimatul Akhlak \\ Institut Ilmu Al-Qur'an Jakarta \\ nurkhalifahku@gmail.com \\ fazakarima25@gmail.com
}

\begin{abstract}
Abstrak
Di era pandemi seperti sekarang ini pembelajaran jarak jauh merupakan salah satu upaya pencegahan penyebaran virus, walaupun pembelajaran jarak jauh terlihat sangat mudah, namun ternyata seringkali terdapat kendala dalam pelaksanaannya yang terkadang mengganggu aktifitas belajar mengajar yang sedang atau akan berlangsung. Tujuan penelitian ini yaitu untuk mengetahui bagaimana pengaruh Pembelajaran Jarak jauh terhadap motivasi belajar Mahasiswi Semester III Program Studi Pendidikan Agama Islam Fakultas Tarbiyah Institut Ilmu Al-Qur'an Jakarta. Adapun yang dijadikan sampel dalam penelitian ini adalah Semester III Program Studi Pendidikan Agama Islam Fakultas Tarbiyah dengan menggunakan teknik pengambilan sampel jenis simple random sampling dengan 35 responden melalui kuesioner yang diisi oleh mahasiswi semester III Institut Ilmu Al-Qur'an. Dari hasil penelitian menunjukan bahwa terdapat korelasi antara pembelajaran jarak jauh terhadap motivasi belajar mahasiswi semester III program studi Pendidikan Agama Islam Fakultas Tarbiyah Institut Ilmu Al-Qur'an Jakarta. Hal ini dibuktikan dengan nilai t hitung sebesar 2,221. Ini menunjukan bahwa nilai t hitung 2,221 > nilai t tabel 2,034. Hal ini menunjukan bahwa Ho ditolak dan Ha diterima. Sehingga dapat disimpulkan bahwa Terdapat pengaruh yang signifikan antara pembelajaran jarak jauh (X) terhadap motivasi belajar mahasiswi (Y).
\end{abstract}

Kata kunci: Motivasi Belajar, Pengaruh Pembelajaran Jarak Jauh.

\begin{abstract}
In the pandemic era like now distance learning is one of the efforts to prevent the spread of the virus, even though distance learning looks very easy, it turns out that there are often obstacles in its implementation that sometimes interfere with teaching and learning activities that are or will take place. The purpose of this study was to determine how the influence of distance learning on the learning motivation of Semester III students of the Islamic Religious Education Study Program, Tarbiyah Faculty of the Al-Qur'an Institute of Sciences, Jakarta. As for the sample in this study is Semester III Islamic Education Study Program, Faculty of Tarbiyah using a simple random sampling type sampling technique with 35 respondents through a questionnaire filled out by third semester students of the Institute of Al-Qur'an Science. The results showed that there was a correlation between distance learning and the learning motivation of the third semester female students of the Islamic Religious Education study program, Tarbiyah Faculty, Al-Qur'an Institute of Sciences, Jakarta. This is evidenced by the $t$ value of 2.221. This shows that the t value is 2.221> the t table value is 2.034. This shows that $\mathrm{Ho}$ is rejected and $\mathrm{Ha}$ is accepted. So it can be concluded that there is a significant influence between distance learning $(X)$ on student learning motivation $(Y)$.
\end{abstract}

Keyword: Learning Motivation, The Influence of Distance Learning.

82 | Faza Karimatul A. dan Nur Kholifah: Pengaruh Pembelajaran Jarak Jauh (PJJ), .... 


\section{A. PENDAHULUAN}

Pendidikan merupakan usaha sadar dan terencana untuk mewujudkan suasana belajar dan proses pembelajaran agar peserta didik secara aktif mengembangkan potensi dirinya untuk memiliki kekuatan spiritual keagamaan, pengendalian diri, kepribadian, kecerdasan akhlak mulia, serta keterampilan yang diperlakukan dirinya, masyarakat, bangsa dan negara. ${ }^{1}$ Oleh karena itu, pendidikan memiliki peran penting dalam mewujudkan pembangunan bangsa. Melalui pendidikan akan lahir masyarakat yang mampu mengamalkan pengetahuan, potensi dan bakat yang dimiliki kepada Negara, Sebab pendidikan adalah tanggung jawab bersama antara pemerintah, masyarakat dan keluarga.

Bermacam-macam faktor yang dapat mempengaruhi tercapainya tujuan pendidikan baik faktor dari peserta didik maupun faktor dari lembaga. Salah satu faktor yang berasal dari diri peserta didik yaitu motivasi belajar yang rendah. Dalam proses belajar motivasi berperan sangat penting. Motivasi yang dimiliki peserta didik akan menentukan hasil yang dicapai dari kegiatan pembelajaran tersebut. Motivasi untuk belajar merupakan kondisi psikis yang dapat mendorong seseorang untuk belajar. Besarnya motivasi setiap siswa tergantung pada faktorfaktor dari siswa itu sendiri, baik dari faktor intrinsik maupun ekstinsik.

Keadaan tempat belajar turut mempengaruhi tingkat keberhasilan belajar, kualitas pendidik, metode mengajarnya kesesuaian kurikulum dengan kemampuan peserta didik, keadaan fasilitas/perlengkapan, keadaan ruangan, jumlah peserta didik perkelas, pelaksanaan tata tertib dan sebagainya, semua ini turut mempengaruhi keberhasilan belajar peserta didik. ${ }^{2}$ Oleh karena itu, untuk dapat menghasilkan prestasi belajar yang baik tidak hanya dipengaruhi oleh faktor motivasi yang berasal dari dalam diri (Intern), tetapi juga dipengaruhi oleh faktor yang berasal dari luar diri (Ekstern) yang salah satunya yaitu metode mengajar yang tepat dan sesuai.

Sejak Coronavirus disasease-2019 atau yang biasa disebut COVID-19 tersebar luas, bahkan hingga menyebabkan pandemi global yang berlangsung sampai saat ini. Pandemi ini sangat berpengaruh terhadap kelangsungan aktifitas masyarakat di seluruh dunia, salah satunya dalam dunia pendidikan, Kementrian Pendidikan dan Kebudayaan (Kemendikbud) turut mengambil kebijakan yang disampaikan melalui surat edaran Nomor 3 Tahun 2020 tentang pencegahan Coronavirus disasease-2019 (COVID-19) Pada satuan Pendidikan (Kemendikbud, 10 Maret 2020). ${ }^{3}$ Kemudian di lanjutkan pada surat edaran Nomor 4 Tahun 2020 tentang pelaksanaan kebijakan pendidikan dalam masa darurat penyebaran Coronavirus disasease-2019 (COVID-19) yang isinya pada poin ke-2 bagian a tentang belajar dari rumah melalui pembelajaran daring/jarak jauh (Kemendikbud, 24 Maret 2020) ${ }^{4}$ sehingga lebih dari

\footnotetext{
${ }^{1}$ Hasbullah, Dasar-dasar Pendidikan, (Jakarta: PT Raja Grafindo Persada, 2005), h.4

${ }^{2}$ M. Dalyono, Psikologi Pendidikan: Komponen MKDK, (Jakarta: Rineka Cipta, 2005), Cet. III, h.

59.

${ }^{3}$ Menteri Pendidikan dan Kebudayaan Republik Indonesia, Surat Edaran Tentang Pencegahan Corona Virus Disease (COVID-19) Pada Saatuan Pendidikan, SE no. SE-03/2020.

${ }^{4}$ Menteri Pendidikan dan Kebudayaan Republik Indonesia, Surat Edaran Tentang Pelaksanaan Kebijakan Pendidikan Dalam Masa Darurat Penyebaran Corona Virus Disease (COVID-19), SE no. SE04/2020, butir 2 .
}

83 | Faza Karimatul A. dan Nur Kholifah: Pengaruh Pembelajaran Jarak Jauh (PJJ), .... 
91\% populasi siswa dunia telah dipengaruhi oleh penutupan sekolah karena pandemi COVID-19. ${ }^{5}$

Menyikapi surat edaran tersebut sampai dengan 18 Maret 2020, tercatat terdapat 276 perguruan tinggi negri dan swasta di indonesia melaksanakan pembelajaran daring/jarakjauh. ${ }^{6}$ dengan berbagai media dan metode yang ditentukan oleh guru atau dosen masingmasing dengan memanfaatkan teknologi.

Cambridge International merilis hasil penelitian Global Education Census yang dilakukan secara global pada tahun 2018 untuk pertamakalinya. Hasil penelitian tersebut menunjukan bahwa pelajar indonesia termasuk pengguna teknologi tertinggi di bidang pendidikan. ${ }^{7}$ Bagi peserta didik di perkotaan seharusnya pembelajaran jarak jauh ini tidak menjadi kendala karena tersedianya fasilitas yang mendukung.

Walaupun pembelajaran jarak jauh terlihat sangat fleksibel karena dapat dilaksanakan dimanapun tidak terikat dalam satu tempat, namun ternyata keputusan pemerintah ini bukan hal mudah untuk diterapkan di Indonesia karena tidak sedikit lembaga pendidikan yang belum terbiasa menggunakan perangkat teknologi dalam proses pembelajarannya. seringkali terdapat kendala dalam pelaksanaannya yang terkadang mengganggu aktifitas belajar mengajar yang sedang atau akan berlangsung, baik yang dialami oleh dosen maupun mahasiswa tersebut, secara teknis seperti keterbatasan jaringan internet yang ada di beberapa daerah maupun materi yang dipelajari seperti kesulitan untuk berkonsentrasi bagi beberapa mahasiswa. terdapat juga keluhan dari para mahasiswa yang mendapat lebih banyak tugas di masa pembelajaran jarak jauh ini yang menyebabkan mahasiswi sedikit bingung untuk menyelesaikannya. Terdapat beberapa peserta didik maupun dosen yang tidak terbiasa berlama-lama menatap layar Handphone maupun Laptop.

Pembelajaran Jarak Jauh baru-baru ini menjadi sangat populer bahkan bukan hanya di Indonesia melainkan di seluruh dunia. Menurut Hamzah B. Uno Pembelajaran jarak jauh adalah sekumpulan metode pengajaran dimana aktivitas pengajaran dilaksanakan secara terpisah dari aktivitas belajar. Pemisah kedua kegiatan tersebut dapat berupa jarak fisik, misalnya karena peserta ajar bertempatan tinggal jauh dari lokasi institusi pendidikan. Pemisah dapat pula jarak non fisik, yaitu berupa keadaan yang memaksa seseorang yang tempat tinggalnya dekat dari lokasi Institusi pendidikan, namun tidak dapat mengikuti kegiatan pembelajaran di Institusi tersebut. Keterpisahan kegiatan pengajaran dari kegiatan belajar adalah ciri yang khas dari pendidikan jarak jauh. Sistem pendidikan jarak jauh merupakan alternatif pemerataan kesempatan dalam bidang pendidikan. Pada sistem pendidikan pelatihan ini tenaga pngajar dan peserta didik tidak harus berada dalam lingkungan geografi yang sama. ${ }^{8}$

Pembelajaran Jarak Jauh sebenarnya bukan metode baru dalam sistem pendidikan. Metode pembelajaran ini telah digunakan di Amerika Serikat sejak tahun 1892 ketika

\footnotetext{
${ }^{5}$ Panduan Pembelajaran Jarak jauh Belajar di Rumah Masa Covid-19 (Pusat Data dan Teknologi Informasi Kementrian Pendidikan dan Kebudayaan, 2020)

${ }^{6}$ https://bebas.kompas.id/baca/riset/2020/03/26/suka-duka-belajar-di-rumah/.

${ }^{7}$ https://news.okezone.com/read/2018/11/21/65/1980696/riset-cambridge-pelajar-indonesiapengguna-teknologi-tertinggi-di-bidang-pendidikan

${ }^{8}$ Hamzah B. Uno, Model Pembelajaran menciptakan proses Belajar Mengajar yang Kreatif dan Efektif, (Jakarta: PT. Bumi Aksara, 2014), h.34
}

84 | Faza Karimatul A. dan Nur Kholifah: Pengaruh Pembelajaran Jarak Jauh (PJJ), .... 
Universitas Chicago meluncurkan program pembelajaran jarak jauh pertamanya untuk tingkat pendidikan tinggi.

Dalam Undang-undang nomor 24 tahun 2012, tentang penyelenggaraan pendidikan jarak jauh pada pendidikan tinggi pasal 6 yang berbunyi, proses pembelajaran PJJ diselenggarakan dengan:

a. Memanfaatkan sumber belajar yang tidak harus berada pada satu temoat yang sama dengan peserta didik

b. Menggunakan modus pembelajaran yang peserta didik dengan pendidiknya terpisah

c. Menekankan belajar secara mandiri, terstruktur, dan terbimbing dengan menggunakan berbagai sumber belajar

d. Memanfaatkan media pembelajaran berbasis teknologi informasi dan komunikasi sebagai sumber belajar yang dapat diakses setiap saat, dan

e. Menekankan interaksi pembelajaran berbasis teknologi informasi dan komunikasi, meskipun tetap memungkinkan adanya pembelajaran tatap muka secara terbatas.

Belajar dari rumah melalui pembelajaran Jarak Jauh, surat edaran Mendikbud Nomor 4 tahun 2020:

a. Memberikan pengalaman belajar yang bermakna bagi siswa, tanpa terbebani tuntutan menuntaskan seluruh capaian kurikulum kenaikan kelas maupun kelulusan.

b. Memfokuskan pada pendidikan kecakapan hidup antara lain mengenai pandemi Covid19

c. Memberikan variasi aktivitas den tugas pembelajaran belajar dari rumah antarsiswa, sesuai minat dan kondisi masing-masing, termasuk mempertimbangkan kesenjangan akses/fasilitas belajar dari rumah.

d. Memberikan umpan balik terhadap bukti atau produk aktivitas belajar dari rumah yang bersifat kualitatif dan berguna bagi guru, tanpa diharuskan memberi skor/nilai kualitatif. ${ }^{9}$ Hamid Muhammad mengatakan masyarakat Indonesia Keliru tentang konsep Pembelajaran Jarak Jauh (PJJ). Ia mengatakan Pembalajaran Jarak Jauh (PJJ) tidak sama dengan pembelajaran Dalam Jaringan (Daring) dalam Pendalaman Panduan Penyelenggaraan Pembelajaran pada tahun ajaran dan tahun akademik baru di masa pandemi COVID-19 secara Virtual (Selasa 16/06/2020). Menurutnya Pembelajaran Jarak Jauh (PJJ) dibagi menjadi dua jenis yaitu pembelajaran Dalam Jaringan (Daring) dan Luar Jaringan (Luring). ${ }^{10}$

a. Pembelajaran Dalam Jaringan (Daring)

Pembelajaran Dalam Jaringan (Daring) ini memiliki beberapa model pembelajaran diantaranya:

1. Model Interaktif berbasis internet seperti Zoom, Google Classroom dan Google Meet seperti yang selama ini dilakukan

2. Learning Manajemen System (LSM) seperti Rumah Belajar milik Kemendikbud dan dari swasta seperti Ruang Guru dan Quipper.

\footnotetext{
${ }^{9}$ Panduan Pembelajaran Jarak jauh Belajar di Rumah Masa Covid-19 (Pusat Data dan Teknologi Informasi Kementrian Pendidikan dan Kebudayaan, 2020)

${ }^{10} \mathrm{https} / / / \mathrm{www} . k 0 m p a s . c o m / \mathrm{edu} / \mathrm{read} / 2020 / 06 / 16 / 200131471 /$ pembelajaran-jarak-jauh-bukanpembelajaran-daring-ini-penjelasannya
}

85 | Faza Karimatul A. dan Nur Kholifah: Pengaruh Pembelajaran Jarak Jauh (PJJ), .... 
Beliau juga mengatakan "Manakala ada hambatan pulsa, gawai, internet dan juga guru tak bisa mengintegrasikan. Itu tak harus Online (Daring), ada juga pilihan lainnya.

b. Pembelajaran Luar Jaringan (Luring)

Salah satu contohnya seperti melalui buku pegangan peserta didik dan guru, bisa juga mengakses lewat televisi dan radio. ${ }^{11}$ Kementrian Pendidikan dan Kebudayaan juga menyediakan media dan sumber pembelajaran Daring:

1. Portal Bersama Hadapi Korona

https://bersamahadapikorona.kemdikbud.go.id

2. Rumah Belajar oleh Pusdatin Kemendikbud

https://belajar.kemdikbud.go.id/

3. TV Edukasi Kemendikbud

https://tve.kemdikbud.go.id/

4. Pembelajaran Digital oleh Pusdatin dan SEAMOLEC Kemendikbud http://rumahbelajar.id/

5. Laman Guru Berbagi

https://guruberbagi.kemdikbud.go.id/

6. SIAJAR oleh SEAMOLEC Kemendikbud

https://lms.seamolec.org/siajar-lms.php

7. Aplikasi Daring untuk Paket A,B,C

http://setara.kemdikbud.go.id/kesetaraan

8. Membaca Digital

http://aksi.puspendik.kemdikbud.go.id/membacadigital/

9. Suara Edukasi

http://suaraedukasi.kemdikbud.go.id/

10. Tatap Muka Daring melalui Program SAPA Duta Rumah Belajar Pusdatin Kemendikbud, melalui Pusdatin.webex.com

11. Program Belajar dari Rumah TVRI. ${ }^{12}$

Adapun kelebihan dari Pembelajaran Jarak Jauh adalah mudah diakses secara online, waktu untuk review tugas menjadi lebih lama, karena tidak ada batasan waktu seperti tatap muka di kelas. Selama masa pandemi ini pun banyak sekali instansi maupun perorangan membagikan e-book secara gratis sehingga siswa dalap mengakses e-book tersebut untuk membaca dan dapat membantu mengerjakan tugas. Untuk mahasiswa pun e-book ini sangat membantu, karena mahasiswa dapat mengakses jurnal-jurnal online untuk membantu mereka mengerjakan tugas.

Walaupun penerapan Pembelajaan Jarak Jauh memiliki banyak kelebihan, tapi ada juga kesulitan selama penerapannya. Banyak sekali siswa dan mahasiswa terlebih orang tua mengeluh tentang pelaksanaan Pembelajaran Jarak Jauh ini. Menurut siswa dan mahasiswa PJJ bukan Pembelajaran Jarak Jauh melainkan Penugasan Jarak Jauh. Selama Pembelajaran

${ }^{11}$ https://www.kompas.com/edu/read/2020/06/16/200131471/pembelajaran-jarak-jauh-bukanpembelajaran-daring-ini-penjelasannya

${ }^{12}$ Panduan Pembelajaran Jarak jauh Belajar di Rumah Masa Covid-19 (Pusat Data dan Teknologi Informasi Kementrian Pendidikan dan Kebudayaan, 2020)

86 | Faza Karimatul A. dan Nur Kholifah: Pengaruh Pembelajaran Jarak Jauh (PJJ), .... 
Jarak Jauh di masa pandemi ini banyak siswa dan mahasiswa yang mengeluh mengenai tugas yang diberikan oleh guru dan dosen, tugas ini dirasa sangat membebani mereka di masa pandemi. Orang tua pun banyak yang mengeluh menganai Pembelajaran Jarak Jauh ini karena banyak tugas yang membingungkan dan tidak dimengerti siswa sehingga orang tua harus turun tangan langsung.

Kendala Pembelajaran Jarak Jauh lainnya adalah sinyal internet, banyak siswa dan mahasiswa yang tinggal di daerah yang cukup sulit jangkauan sinyal, sehingga ini menyulitkan mereka untuk melakukan Pembelajaran Jarak Jauh ini. Kendala lainnya adalah banyak siswa yang tidak memiliki gawai, komputer, dan laptop sehingga cukup menylitkan dalam pelaksanaannya.

Walaupun terdapat kelebihan dan kekurangan dalam pelaksanaan Pembelajaran Jarak Jauh, tapi pendidikan harus tetap dijalankan sesuai dengan keadaan yang terjadi, karena tidak mungkin apabila pendidikan harus dihentikan. Maka dari itu baik pendidik maupun peserta didik harus melaksanakan Pembelajaran Jarak Jauh sebaik mungkin agar pelaksanaan pendidikan tetap berjalan dengan baik ${ }^{13}$

Motivasi adalah upaya-upaya yang dilakukan untuk menimbulkan atau meningkatkan motif. Motif merupakan motor penggerak dinamika prilaku individu dalam mencapai tujuan. Kualitas dinamika perilaku akan bergantung pada kekuatan motif sebagai sumber penggeraknya. Oleh karena itu, dalam upaya membuat agar perilaku berlangsung dengan dinamika gerakan yang kuat maka perlu dilakukan upaya untuk menimbulkan atau meningkatkan motif. Misalnya guru harus mengupayakan agar peserta didik terdorong untuk lebih giat belajar, pimpinan harus mengupayakan berbagai strategi agar para bawahan terdorong untuk kerja lebih giat dan produktif, para pedagang harus mengupayakan agar konsumen terdorong untuk membeli dagangannya. ${ }^{14}$

Dalam kamus besar bahasa Indonesia motivasi adalah suatu dorongan yang timbul pada seseorang secara sadar untuk melakukan suatu tindakan dengan tujuan tertentu. Perbuatan pencapaian tujuan ini melahirkan kepuasan pada diri seseorang. Tidak bisa dipungkiri, setiap tindakan yang dilakukan oleh manusia selalu dimuali dengan motivasi (niat) sebagaimana sabda Rasulullah Saw,

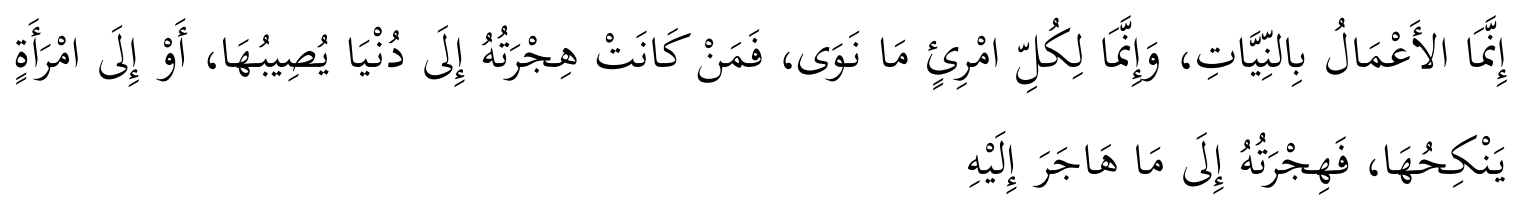

"Sesungguhnya setiap amal perbuatan bergantung pada niatnya, dan bagi setiap orang apa yang ia niatkan. Barang siapa yang hijrahnya karena urusan dunia yang ingin

${ }^{14}$ Mohamad Surya, Psikologi Guru Konsep dan Aplikasi dari Guru, untuk Guru, (Bandung: Aalfabeta, 2013) h.58
}

${ }^{13}$ https://kumparan.com/frida-rohmyni/kelebihan-dan-kekurangan-pji-di-masa-pandemi-covid-19-

87 | Faza Karimatul A. dan Nur Kholifah: Pengaruh Pembelajaran Jarak Jauh (PJJ), .... 
diraihnya atau karena wanita yang ingin dinikahinya maka hijrahnya sesuai dengan yang ia niatkan."

Setiap orang memiliki motivasi yang berbeda antara satu dengan yang lainnya, terdapat banyak hal yang dapat mempengaruhi motivasi dalam diri seseorang. Menurut Darsono yang dikutip oleh Fadhilah Suralaga dan Solicha dalam buku Psikologi Pendidikan bahwa faktorfaktor yang dapat mempengaruhi motivasi ada 6 macam antara lain:

a. Kondisi peserta didik

Kondisi peserta didik sangat berpengaruh pada motivasi belajarnya. Kondisi peserta didik sendiri meliputi kesehatan rohani maupun jasmani. Apabila peserta didik dalam keadaan yang kurang sehat maka peserta didik tersebut akan sulit menerima pelajaran yang disampaikan, karena fisik yang lemah akan mempengaruhi motivasi dari diri peserta didik tersebut.

b. Cita-cita atau aspirasi pembelajaran

Cita-cita adalah sebuah keinginan atau tujuan yang ingin dicapai, cita-cita itu beragam karena setiap peserta didik pasti memiliki cita-cita yang berbeda. Aspirasi atau taraf keberhasilan dan bisa digunakan untuk mengukur apakah peserta didik berhasil atau tidak untuk mencapai keinginaannya.

c. Unsur-unsur dinamis dalam belajar

Merupakan unsur yang terdapat dalam proses belajar yang bersifat tidak stabil seperti kondisi emosional peserta didik.

d. Kondisi lingkungan

Kondisi lingkungan datang dari luar diri peserta didik. Contohnya lingkungan sekolah, masyarakat, dan keluarga.

e. Upaya guru dalam menyampaikan pelajaran

Upaya yang dilakukan guru dalam mengajar adalah bagaimana cara guru tesebut mempersiapkan materi dengan baik, menyampaikan materi tersebut dengan menarik dan mengevaluasi proses belajar peserta didik. Sehingga peserta didik dapat memahami materi dengan baik.

f. Kemampuan belajar

Kemampuan peserta didik meliputi kecakapan atau penguasaan peserta didik dalam menyelesaikan sebuah tugas yang diberikan oleh guru. Seorang peserta didik yang memiliki kemampuan belajar yang tinggi biasanya dikarenakan peserta didik tersebut memiliki motivasi dalam belajarnya. ${ }^{15}$

${ }^{15}$ Fadhilah Suralaga dan Solicha, Psikologi Pendidikan, (Ciputat: Lembaga Penelitian UIN Syarif Hidayatullah Jakarta, 2010), h.104-105

88 | Faza Karimatul A. dan Nur Kholifah: Pengaruh Pembelajaran Jarak Jauh (PJJ), .... 


\section{B. METODE PENELITIAN}

Jenis penelitian yang di gunakan dalam penelitaian ini merupakan pendekatan kuantitatif. Pendekatan penelitian ini menggunakan pendekatan kuantitatif karena menggunakan angka, mulai dari pengumpulan data, penafsiran terhadap data tersebut, serta penampilan dari hasilnya.

Penelitian ini dirancang dengan menggunakan metode kuantitatif korelasional, yaitu untuk menguji hubungan antar variabel, berdasarkan data kuantitatif yang kemudian dilakukan pengolahan dan analisis data dengan menggunakan statistika. Dalam hal ini Penelitian yang dilakukan bertujuan untuk mengetahui apakah proses pembelajaran jarak jauh mempengaruhi motivasi belajar mahasiswi semester III program studi Pendidikan Agama Islam Institut Ilmu al-Qur'an Jakarta dengan jumlah responden sebanyak 35 mahasiswa.

Instrumen Penelitian yang digunakan untuk mengumpulkan data dalam penelitian ini adalah kuesioner, yaitu kuisioner yang sudah disediakan alternatif jawabannya sehingga responden tinggal memilih, hal ini akan memudahkan responden dalam menjawab.

Tabel 1

Kisi-kisi Instrumen Penelitian

\begin{tabular}{|c|c|c|c|c|}
\hline No & Variabel & Indikator & $\begin{array}{l}\text { Nomor } \\
\text { Butir }\end{array}$ & Jumlah \\
\hline 1 & \multirow{3}{*}{$\begin{array}{l}\text { Pembelajaran } \\
\text { Jarak Jauh }\end{array}$} & $\begin{array}{l}\text { Pembelajaran Jarak Jauh menjadi salah } \\
\text { satu metode efektif dalam } \\
\text { melaksanakan Kegiatan Belajar } \\
\text { Mengajar }\end{array}$ & $1,2,3$ & 3 \\
\hline 2 & & $\begin{array}{l}\text { Kemajuan Teknologi dan Informasi } \\
\text { memudahkan Kegiatan Belajar } \\
\text { Mengajar }\end{array}$ & $4,5,6$ & 3 \\
\hline 3 & & $\begin{array}{l}\text { Pembelajaran Jarak Jauh yang Fleksibel } \\
\text { memudahkan Kegiatan Belajar } \\
\text { Mengajar }\end{array}$ & $7,8,9,10$ & 4 \\
\hline 4 & \multirow{8}{*}{ Motivasi Belajar } & $\begin{array}{l}\text { Kehadiran dalam Kegiatan Belajar } \\
\text { Mengajar }\end{array}$ & 1 & 1 \\
\hline 5 & & $\begin{array}{l}\text { Belajar di luar Kegiatan Belajar } \\
\text { Mengajar }\end{array}$ & 2 & 1 \\
\hline 6 & & $\begin{array}{l}\text { Sikap menghadapi kesulitan dalam } \\
\text { belajar }\end{array}$ & $3,4,5,6$ & 4 \\
\hline 7 & & $\begin{array}{l}\text { Kebisaan dalam mengikuti Kegiatan } \\
\text { Belajar Mengajar }\end{array}$ & 7,8 & 3,4 \\
\hline 8 & & $\begin{array}{l}\text { Semangat dalam mengikuti Kegiatan } \\
\text { Belajar Mengajar }\end{array}$ & 9,10 & \\
\hline 9 & & Keinginan untuk berprestasi & 11 & \\
\hline 10 & & Kualifikasi hasil & 12,13 & \\
\hline 11 & & Penyelesaian tugas & 14,15 & \\
\hline
\end{tabular}

89 | Faza Karimatul A. dan Nur Kholifah: Pengaruh Pembelajaran Jarak Jauh (PJJ), .... 


\begin{tabular}{|c|l|l|c|c|}
\hline 12 & & $\begin{array}{l}\text { Memiliki cita-cita dan harapan masa } \\
\text { depan }\end{array}$ & 16 & $\begin{array}{l}\text { Adanya guru yang kompeten dan } \\
\text { menarik dalam belajar }\end{array}$ \\
\cline { 3 - 4 } 13 & $17,18,19$ & \\
\hline
\end{tabular}

\section{HASIL DAN PEMBAHASAN}

Data tentang pengaruh pembelajaran jarak jauh terhadap motivasi mahasiswa semester III Tarbiyah PAI yang diperoleh melalui kuesioner. Yang kemudian dari hasil angket tersebut diolah dengan uji normalitas, uji korelasi sederhana (uji hipotesis), uji koefisien regresi sederhana, uji koefisien determinasi (R square), dan pengujian hipotesis.

Table 2

Hasil Kuisioner Variabel $\mathbf{X}$

\begin{tabular}{|c|l|c|c|}
\hline \multirow{2}{*}{ No } & \multirow{2}{*}{ Responden } & \multicolumn{2}{|c|}{ Pembelajaran Jarak Jauh } \\
\cline { 2 - 4 } & & skor & Nilai \\
\hline 1 & R-1 & 25 & 2.5 \\
\hline 2 & R-2 & 21 & 5 \\
\hline 3 & R-3 & 32 & 7.5 \\
\hline 4 & R-4 & 23 & 10 \\
\hline 5 & R-5 & 13 & 12.5 \\
\hline 6 & R-6 & 22 & 15 \\
\hline 7 & R-7 & 19 & 17.5 \\
\hline 8 & R-8 & 24 & 20 \\
\hline 9 & R-9 & 22 & 22.5 \\
\hline 10 & R-10 & 30 & 25 \\
\hline 11 & R-11 & 23 & 27.5 \\
\hline 12 & R-12 & 30 \\
\hline 13 & R-13 & 22 & 32.5 \\
\hline 14 & R-14 & 35 \\
\hline 15 & R-15 & 21 & 37.5 \\
\hline 16 & R-16 & 17 & 40 \\
\hline 17 & R-17 & 32 & 42.5 \\
\hline 18 & R-18 & 20 & 45 \\
\hline 19 & R-19 & 24 & 47.5 \\
\hline 20 & R-20 & 27 & 50 \\
\hline 21 & R-21 & 27 & 52.5 \\
\hline 22 & R-22 & 22 & 55 \\
\hline 23 & R-23 & 28 & 57.5 \\
\hline 24 & R-24 & 23 & 60 \\
\hline 25 & R-25 & 31 & 67.5 \\
\hline 26 & R-26 & \\
\hline 27 & R-27 & 28 & 17 \\
\hline
\end{tabular}




\begin{tabular}{|c|l|c|c|}
28 & R-28 & 25 & 70 \\
\hline 29 & R-29 & 26 & 72.5 \\
\hline 30 & R-30 & 23 & 75 \\
\hline 31 & R-31 & 24 & 77.5 \\
\hline 32 & R-32 & 27 & 80 \\
\hline 33 & R-33 & 23 & 82.5 \\
\hline 34 & R-34 & 28 & 85 \\
\hline 35 & R-35 & 22 & 87.5 \\
\hline
\end{tabular}

Tabel 3

Hasil Kuisioner Variabel Y

\begin{tabular}{|c|l|c|c|}
\hline \multirow{2}{*}{ No } & \multirow{2}{*}{ Responden } & \multicolumn{2}{|c|}{ Motivasi Belajar } \\
\cline { 3 - 4 } & & Skor & Nilai \\
\hline 1 & R-1 & 57 & 75 \\
\hline 2 & R-2 & 50 & 65.7 \\
\hline 3 & R-3 & 70 & 92.1 \\
\hline 4 & R-4 & 58 & 76.3 \\
\hline 5 & R-5 & 73 & 96 \\
\hline 6 & R-6 & 60 & 78.9 \\
\hline 7 & R-7 & 45 & 59.2 \\
\hline 8 & R-8 & 58 & 76.3 \\
\hline 9 & R-9 & 52 & 68.4 \\
\hline 10 & R-10 & 65 & 85.5 \\
\hline 11 & R-11 & 57 & 75 \\
\hline 12 & R-12 & 81.5 \\
\hline 13 & R-13 & 62 & 75 \\
\hline 14 & R-14 & 57 & 75 \\
\hline 15 & R-15 & 57 & 75 \\
\hline 16 & R-16 & 57 & 88.1 \\
\hline 17 & R-17 & 67 & 84.2 \\
\hline 18 & R-18 & 64 & 76.3 \\
\hline 19 & R-19 & 58 & 89.4 \\
\hline 20 & R-20 & 68 & 85.5 \\
\hline 21 & R-21 & 64.4 \\
\hline 22 & R-22 & 65 & 84.2 \\
\hline 23 & R-23 & 49 & 69.7 \\
\hline 24 & R-24 & 64 & 88.1 \\
\hline 25 & R-25 & 53 & 67.5 \\
\hline 26 & R-26 & 67 & \\
\hline 27 & R-27 & 67 & \\
\hline & & 59 & \\
\hline
\end{tabular}

91 | Faza Karimatul A. dan Nur Kholifah: Pengaruh Pembelajaran Jarak Jauh (PJJ), .... 


\begin{tabular}{|l|l|l|l|}
28 & R-28 & 59 & 77.6 \\
\hline 29 & R-29 & 55 & 72.3 \\
\hline 30 & R-30 & 51 & 67.1 \\
\hline 31 & R-31 & 64 & 84.2 \\
\hline 32 & R-32 & 72 & 72.3 \\
\hline 33 & R-33 & 90 & 90.7 \\
\hline 34 & R-34 & 68 & 68.4 \\
\hline 35 & R-35 & 78 & 78.9 \\
\hline
\end{tabular}

Tabel 4

Hasil Analisis Uji Normalitas

\begin{tabular}{|l|c|c|}
\hline \multicolumn{2}{|c|}{ One-Sample Kolmogorov-Smirnov Test } \\
\hline \multicolumn{2}{|c|}{} & $\begin{array}{c}\text { Unstandardized } \\
\text { Residual }\end{array}$ \\
\hline $\mathrm{N}$ & Mean & $\mathbf{3 5}$ \\
\hline Normal Parameters & a,b & 0000000 \\
\cline { 2 - 3 } & Std. Deviation & 6.49013150 \\
\hline $\begin{array}{l}\text { Most Extreme } \\
\text { Differences }\end{array}$ & Absolute & .091 \\
\cline { 2 - 3 } & Positive & .081 \\
\hline Test Statistic & Negative & -.091 \\
\hline Asymp. Sig. (2-tailed) & & .091 \\
\hline
\end{tabular}

Dari table tersebut menunjukan nilai tes statistic Kolmograv-Smirnov > 0,05 yakni 0,0200 sehingga dapat disimpulkan bahwa data yang digunakan berdistribusi normal. Hasil uji normalitas pada data-data tersebut tidakberdistribusi normal, namun diatasi dengan outliers pada SPSS versi 21.

Tabel 5

Hasil Analisis Uji Korelasi

\begin{tabular}{|c|c|c|c|}
\hline \multicolumn{4}{|c|}{ Correlations } \\
\hline & & $\begin{array}{c}\text { Pembelajaran } \\
\text { Jarak Jauh }\end{array}$ & $\begin{array}{c}\text { Motivasi } \\
\text { Belajar }\end{array}$ \\
\hline \multirow{3}{*}{$\begin{array}{l}\text { Pembelajaran } \\
\text { Jarak Jauh }\end{array}$} & $\begin{array}{l}\text { Pearson } \\
\text { Correlation }\end{array}$ & 1 & $.361^{*}$ \\
\hline & Sig. (2-tailed) & & .033 \\
\hline & $\mathrm{N}$ & 35 & 35 \\
\hline \multirow{3}{*}{$\begin{array}{l}\text { Motivasi } \\
\text { Belajar }\end{array}$} & $\begin{array}{l}\text { Pearson } \\
\text { Correlation }\end{array}$ & $.361^{*}$ & 1 \\
\hline & Sig. (2-tailed) & .033 & \\
\hline & $\mathrm{N}$ & 35 & 35 \\
\hline
\end{tabular}

92 | Faza Karimatul A. dan Nur Kholifah: Pengaruh Pembelajaran Jarak Jauh (PJJ), .... 
Berdasarkan data diatas maka dapat disimpulkan terdapat korelasi antara variabel (X) Pembelajaran Jarak Jauh dengan variabel (Y) Motivasi Belajar karena nilai signifikansi < 0,05 yakni 0,03 . Adapun untuk kekuatan korelasi adalah kuat dengan tingkat korelasi sebesar 0,361 .

Tabel 6

Hasil Analisis Uji Koefesien Regresi

\begin{tabular}{|l|c|c|c|c|c|}
\hline \multicolumn{5}{|c|}{ Coefficients $^{\text {a }}$} \\
\hline & \multicolumn{2}{|c|}{$\begin{array}{c}\text { Unstandardized } \\
\text { Coefficients }\end{array}$} & $\begin{array}{c}\text { Standar } \\
\text { dized } \\
\text { Coeffic } \\
\text { ients }\end{array}$ & & \\
Model & $\mathrm{B}$ & $\begin{array}{c}\text { Std. } \\
\text { Error }\end{array}$ & Beta & $\mathrm{t}$ & Sig \\
\hline 1 (Constant) & 44.810 & 6.548 & & 6.843 & .000 \\
\hline $\begin{array}{l}\text { Pembelajara } \\
\text { n Jarak Jauh }\end{array}$ & .598 & .269 & .361 & 2.221 & .033 \\
\hline a.Dependent Variable: Motivasi Belajar & \\
\hline
\end{tabular}

Berdasarkan tabel 6 diperoleh koefisien regresi sederhana sebagai berikut:

$\mathrm{Y}=\mathrm{a}+\mathrm{b} \mathrm{X}$

$\mathrm{Y}=44,810+0,598 \mathrm{X}$

a. Konstanta sebesar 44,810 mengandung arti bahwa nilai konsisten variabel Pembelajaran Jarak Jauh sebesar 44,810

b. Koefisiensi regresi X sebesar 0,598 menyatakan bahwa setiap penambahan $1 \%$ nilai variabel X maka nilai variabel Y bertambah sebesar 0,598. Koefisien regresi tersebut bernilai positif, sehingga dapat dikatakan bahwa arah pengaruh variabel X terhadap $\mathrm{Y}$ adalah positif.

Tabel 7

Hasil Analisis Uji Korefesien Determinasi

\begin{tabular}{|c|c|r|r|r|}
\hline \multicolumn{5}{|c|}{ Model Summary $^{\mathbf{b}}$} \\
\hline Model & $\mathrm{R}$ & $\mathrm{R}$ Square & $\begin{array}{l}\text { Adjusted } \\
\text { R Square }\end{array}$ & $\begin{array}{r}\text { Std. Error of } \\
\text { the Estimate }\end{array}$ \\
\hline 1 & $.361^{\mathrm{a}}$ & .130 & .104 & 6.588 \\
\hline
\end{tabular}

a. Predictors: (Constant), Pembelajaran Jarak Jauh

b. Dependent Variable: Motivasi Belajar

Berdasarkan tabel 4.8 diketahui nilai koefesien determinasi atau R Square adalah sebesar 0,130. Nilai R Square 0,130 berasal dari output yaitu sebesar 0,361. Dengan pengertian 
bahwa pengaruh variabel X Pembelajaran Jarak Jauh terhadaap variabel Y Motivasi Belajar adalah sebesar $13,0 \%$ atau $13 \%$.

Hipotesis merupakan jawaban sementara terhadap rumusan masalah penelitian, dimana rumusan masalah penelitian telah dinyatakan dalam bentuk kalimat pertanyaan. ${ }^{16}$ Hipotesis statistik dalam penelitian ini adalah:

$\mathrm{Ha} \rightarrow \mathrm{p}=0:$ Terdapat pengaruh yang signifikan antara pembelajaran jarak jauh terhadap motivasi belajar mahasiswi.

Ho $\rightarrow \mathrm{p} \neq$ : Tidak terdapat pengaruh yang signifikan antara pembelajaran jarak jauh terhadap motivasi belajar mahasiswi

Uji hipotesis t dilakukan dengan menguji dua sisi dengan membandingkan nilai t hitung dengan t tabel pada taraf signifikan $5 \%(0,05: 2=0,025)$ sebagai berikut

$$
\begin{aligned}
& \text { Df }=n-2 \\
& \text { Df }=35-2 \\
& \text { Df }=33 \\
& \text { t tabel }=(33: 0,025)=2,0345
\end{aligned}
$$

\section{Tabel 8}

\section{Hasil Analisis Uji Hipotesis t Pembelajaran Jarak Jauh (X) terhadap Motivasi Belajar}

(Y)

\begin{tabular}{|l|c|c|c|c|c|}
\hline \multicolumn{7}{|c|}{ Coefficients $^{\text {a }}$} \\
\hline & $\begin{array}{c}\text { Unstandardized } \\
\text { Coefficients }\end{array}$ & $\begin{array}{c}\text { Standar } \\
\text { dized } \\
\text { Coeffic } \\
\text { ients }\end{array}$ & & \\
Model & $\mathrm{B}$ & $\begin{array}{c}\text { Std. } \\
\text { Error }\end{array}$ & Beta & $\mathrm{t}$ & Sig \\
\hline 1 (Constant) & 44.810 & 6.548 & & 6.843 & .000 \\
\hline $\begin{array}{l}\text { Pembelajara } \\
\text { n Jarak Jauh }\end{array}$ & .598 & .269 & .361 & 2.221 & .033 \\
\hline \multicolumn{7}{|l|}{ a.Dependent Variable: Motivasi Belajar } \\
\hline
\end{tabular}

Berdasarkan tabel 4.9 dapat diketahui bahwa nilai t hitung sebesar 2,221. Ini menunjukan bahwa nilai t hitung 2,221 > nilai t tabel 2,034. Hal ini menunjukan bahwa Ho ditolak dan Ha diterima. Sehingga dapat disimpulkan bahwa Terdapat pengaruh yang signifikan antara pembelajaran jarak jauh (X) terhadap motivasi belajar mahasiswi (Y).

\footnotetext{
${ }^{16}$ Sugiyono, Metode Penelitian Pendidikan Pendekatan Kuantitatif, Kualitatif, dan R\&D, h.96
} 
Tabel 9

Data Deskriptif Pembelajaran Jarak Jauh

\begin{tabular}{|l|l|l|}
\hline \multicolumn{2}{|c|}{ Statistics } \\
\hline Total_X & Valid & 35 \\
\cline { 2 - 3 } & Missing & 0 \\
\hline Mean & 59.93 \\
\hline Std. Error of Mean & 1.774 \\
\hline Std. Deviation & 10.493 \\
\hline Variance & 110.105 \\
\hline Range & 48 \\
\hline Minimum & 33 \\
\hline Maximum & 80 \\
\hline
\end{tabular}

Berdasarkan tabel tersebut maka diperoleh data bahwa rata-rata skor total data pembelajatan jarak jauh adalah 59,93 dengan rentang nilai 48 dari nilai terendah 33 dan nilai tertinggi 80 .

Tabel 10

Data Deskriptif Motivasi Belajar

\begin{tabular}{|l|l|l|}
\hline \multicolumn{2}{|c|}{ Statistics } \\
\hline Total_X & Valid & 35 \\
\cline { 2 - 3 } & Missing & 0 \\
\hline Mean & 77.82 \\
\hline Std. Error of Mean & 1.548 \\
\hline Std. Deviation & 9.156 \\
\hline Variance & 83.830 \\
\hline Range & 37 \\
\hline Minimum & 59 \\
\hline Maximum & 96 \\
\hline
\end{tabular}

Berdasarkan tabel tersebut maka diperoleh data bahwa rata-rata skor total data pembelajatan jarak jauh adalah 77,82 dengan rentang nilai 37 dari nilai terendah 59 dan nilai tertinggi 96. 


\section{KESIMPULAN}

Berdasarkan hasil analisis dan pembahasan yang telah diuraikan sebelumnya serta didasarkan atas hasil analisis data yang disebutkan dalam bab-bab sebelumnya maka dapat ditarik kesimpulan dari keseluruhan hasil penelitian bahwa, Terdapat korelasi antara pembelajaran jarak jauh terhadap motivasi belajar mahasiswi semester III program studi Pendidikan Agama Islam Fakultas Tarbiyah Institut Ilmu Al-Qur'an Jakarta. Hal ini dibuktikan dengan nilai $t$ hitung sebesar 2,221. Ini menunjukan bahwa nilai t hitung 2,221 > nilai t tabel 2,034. Hal ini menunjukan bahwa Ho ditolak dan Ha diterima. Sehingga dapat disimpulkan bahwa Terdapat pengaruh yang signifikan antara pembelajaran jarak jauh (X) terhadap motivasi belajar mahasiswi (Y). Kontribusi pembelajaran jarak jauh terhadap motivasi belajar mahasiswi semester III program studi Pendidikan Agama Islam Fakultas Tarbiyah Institut Ilmu Al-Qur'an Jakarta adalah sebesar 13\% dan sisanya 87\% dipengaruhi oleh faktor lain yang tidak diteliti di penelitian ini.

Pelaksanaan pembelajaran jarak jauh berjalan dengan lancar, namun dirasakan sebagian besar dosen dan mahasiswa kurang ideal dibandingkan pembelajaran tatap muka secara konvensional. Komunikasi terjalin kurang lancar menyebabkan materi menjadi sulit dipahami terutama mata kuliah praktikum. Hasil belajar mahasiswa dengan pembelajaran daring bervariasi, mulai dari kurang memuaskan, cukup hingga baik. kendala yang dihadapi mahasiswa dan dosen dalam pembelajaran daring adalah : ketersediaan kuota internet, jaringan yang terkadang tidak stabil, dan alat penunjang (Gawai dan Laptop). Pembelajaran daring dinilai oleh sebagian informan efektif jika diterapkan pada masa pandemi covid-19 karena berkaitan dengan protokol kesehatan. Diperlukan model pembelajaran daring yang lebih variatif sebagai alternatif yang dapat digunakan dimasa mendatang agar pembelajaran tetap menarik sehingga tujuan dari pendidikan secara umum dapat tercapai. 


\section{E. DAFTAR PUSTAKA}

Hasbullah. 2005. Dasar-dasar Pendidikan. Jakarta: PT Raja Grafindo Persada

Dalyono. M. 2005. Psikologi Pendidikan: Komponen MKDK. Jakarta: Rineka Cipta

Menteri Pendidikan dan Kebudayaan Republik Indonesia, Surat Edaran Tentang Pencegahan Corona Virus Disease (COVID-19) Pada Saatuan Pendidikan, SE no. SE-03/2020.

Panduan Pembelajaran Jarak jauh Belajar di Rumah Masa Covid-19 (Pusat Data dan Teknologi Informasi Kementrian Pendidikan dan Kebudayaan, 2020)

Uno. Hamzah B. 2014. Model Pembelajaran menciptakan proses Belajar Mengajar yang Kreatif dan Efektif. Jakarta: PT. Bumi Aksara

Surya. Mohamad. 2013. Psikologi Guru Konsep dan Aplikasi dari Guru, untuk Guru. Bandung: Aalfabeta

Suralaga. Fadhilah dan Solicha. 2010. Psikologi Pendidikan. Ciputat: Lembaga Penelitian UIN Syarif Hidayatullah Jakarta

Sugiyono. 2016. Metode Penelitian Pendidikan Pendekatan Kuantitatif, Kualitatif, dan R\&D. Bandung: Alfabeta

Kompas, Suka duka belajar dirumah, lihat https://bebas.kompas.id/baca/riset/2020/03/26/suka-duka-belajar-di-rumah/

Menteri Pendidikan dan Kebudayaan Republik Indonesia, Surat Edaran Tentang Pelaksanaan Kebijakan Pendidikan Dalam Masa Darurat Penyebaran Corona Virus Disease (COVID-19), SE no. SE-04/2020, butir 2. 